Ryszarda M. BULAS*

\title{
PALESTYŃSKIE AMPUŁKI ZE ZBIORÓW MONZA - BOBBIO. PROGRAM IKONOGRAFICZNY
}

Bobbio, położone w północnej Italii, znane było już w starożytności jako Bobium lub Ebovium, istnieją w nim również pozostałości osad celtyckich, jednak sławne stało się w Europie dopiero od VII wieku, kiedy to irlandzki mnich św. Kolumban Młodszy (561-615') założył tam klasztor. W ciągu następnych 200 lat stało się Bobbio najważniejszym ośrodkiem monastycznym Italii Północnej. Św. Kolumban wywodził się z irlandzkiego klasztoru w Bangor gdzie studiował pod kierunkiem św. Comgalla². W 590 r. wyruszył w podróż na kontynent europejski w towarzystwie mnichów i przez kilkanaście lat działał w królestwie Merowingów zakładając klasztory (Annegrey, Luxeuil i Fontaine) $)^{3}$. W wyniku konfliktu z merowińskim królem Childebertem udał się na południe, do Północnej Italii, do królestwa Longobardów. Tam z inicjatywy króla Agilufa założył w 613 r. klasztor w Bobbio. Wkrótce po założeniu, klasztor przyjął regułę benedyktyńską, popularną także w środowisku irlandzkich klasztorów w Galii i Germanii ${ }^{4}$. W VIII w. powstała w Bobbio słynna biblioteka i skryptorium ${ }^{5}$. W późniejszym okresie gościło ono wielu mnichów pragnących odwiedzić grób fundatora, także dlatego, że było ono dla nich

* Dr hab. Ryszarda M. Bulas - były pracownik Katedry Historii Sztuki Starożytnej i Wczesnochrześcijańskiej w Instytucie Historii Sztuki na Wydziale Nauk Humanistycznych Katolickiego Uniwersytetu Lubelskiego Jana Pawła II; e-mail: ryszardalas@gmail.com.

${ }^{1}$ Trwa dyskusja na temat daty śmierci św. Kolumbana (616 r.?), zob. J. Strzelczyk, Wstęp, w: Jonasz z Bobbio, Żywot Kolumbana, tłum. E. Zakrzewska-Gębka - A. Mikołajczak, PSP 60, Warszawa 1995, 43.

${ }^{2}$ Por. R. Bulas, Od Amergina do Book of Kells. Piśmiennictwo w Irlandii wczesnośredniowiecznej (w druku).

${ }^{3} \mathrm{Na}$ temat zakładanych przez Kolumbana i jego uczniów klasztorów w merowińskiej Galii zob. A. O'Hara, The Vita Columbani in Merovingian Gaul, „Early Medieval Europe” 17 (2009) 124-153.

${ }^{4}$ Por. P.-A. Février, Le monachisme, w: Naissance des arts chrétiens. Atlas des monuments paléochrétiens de la France, Paris 1991, 144-145 (Règle de Columban et Règle bénédictine).

${ }^{5} \mathrm{Na}$ temat biblioteki i skryptorium zob. P. Riché, Edukacja i kultura w Europie zachodniej (VI-VIII), Warszawa 1995; J.F. Kenney, The Sources for the Early History of Ireland. An Introduction and Guide, I, New York 1929, 84-87 (Bobbio, Sankt Gallen, Carlsruhe [Reichenau] i Louvain); P. Engelbert, Zum Frühgeschichte des Bobbio Scriptorium, RBen 78 (1968) 220-260. 
przystankiem w pielgrzymowaniu do Jerozolimy ${ }^{6}$. Obydwa ośrodki, w których znaleziono ampułki - Bobbio i Monza, a także stolica Longobardów Pawia, we wczesnym okresie formowania się kultury Longobardów były ze sobą ściśle związane. W Monzie, położonej na północ od Mediolanu, królowa Teodolinda $(† 628)^{7}$ wzniosła kościół i pałac, w którym przyjmowała także artystów $^{8}$. Tak o tym czasie pisał Paweł Diakon, autor Historii Longobardów:

„Król Agilulf, zwany także Agon, po dwudziestu pięciu latach panowania zamknął oczy, przekazawszy władzę w ręce nieletniego jeszcze syna Adaloalda i jego matki Teudelindy. Za ich rządów odbudowano wiele kościołów i poczyniono liczne darowizny na rzecz świętych miejsc"".

W Monzie i Bobbio znaleziono grupę małych metalowych ampułek ${ }^{10}$, pochodzących prawdopodobnie z kolekcji elogiów, zgromadzonych przez królową Longobardów Teodolindę. Na podstawie zapisków znalezionych w krypcie św. Kolumbana wiadomo, że niejaki Jan przywiózł te ampułki z Rzymu od papieża Grzegorza Wielkiego w darze dla longobardzkiej królowej ${ }^{11}$. Ponieważ niektóre z nich znaleziono przy zwłokach św. Kolumbana można je datować na ok. 600 rok $^{12}$.

Ampułki z grupy Bobbio - Monza mają kształt spłaszczonej okragłej buteleczki, z krótką szyjką, do której przytwierdzony jest łańcuszek; obie strony pokryte są repusowaną dekoracją. W celu wzmocnienia i umieszczenia uchwytu, dwa brzuśce ujęte zostały w obręcz ściśniętą na szyjce drutem lub

\footnotetext{
${ }^{6}$ Na temat Bobbio zob. Riché, Edukacja i kultura, s. 354-355 i 412; E. Derdziuk, Mnisi iroszkoccy. Św. Kolumban Młodszy - ewangelizacja Europy, Lublin 1997, 100-103.

${ }^{7}$ Teodolinda ( $†$ 628) była bawarską katoliczką, córką Garibalda króla Bawarów. Na jej temat zob. Historia powszechna, VII: Od cesarstwa rzymskiego do ekspansji islamu. Karol Wielki, red. L. Serafini, Novara 2007, 70-71; L. Nees, Early Medieval Art, Oxford 2002, 107, 119, il. 64; P. Subiszewski, Sztuka Europy łacińskiej od VI-IX wieku, tłum. J. Kuczyńska - E. Zwolski, Lublin 2001, 19.

${ }^{8}$ Por. Riché, Edukacja i kultura w Europie zachodniej, s. 349.

${ }^{9}$ Paulus Diaconus, Historia Langobardorum IV 41, ed. L. Bethmann - G. Waitz, MGH Scriptores rerum Langobardicarum et Italicarum saec. VI-IX 1, Hannoverae 1878, 133, thum. I. Lewandowski: Paweł Diakon, Historia Longobardów, Warszawa 1995, 277.

${ }^{10}$ Po polsku na ten temat zob. E. Jastrzębowska, Najstarsze zachowane dewocjonalia pielgrzymie z Jerozolimy, w: Jerozolima w kulturze europejskiej, red. P. Paszkiewicz - T. Zadrożny, Warszawa 1997, 59-69; E. Jastrzębowska, Daniel i Tekla między lwami: antyczne korzenie sceny, w: Studia z poczatków ikonografii chrześcijańskiej, red. E. Jastrzębowska, Warszawa 1998, 25-57; F.W. Deichmann, Archeologia chrześcijańska, tłum. E. Jastrzębowska, Warszawa 1994, 25.

${ }^{11}$ Por. N. Aberg, The Occident and the Orient in the Art of the Seventh Century, part 2: Lombard Italy, Stockholm 1945, 79. W skarbcu kościoła w Monza znaleziono spis ampułek przesłanych Teodolindzie przez papieża Grzegorza I zatytułowany „Notula de olea Sanctorum martyrum qui Romae in corpore requiescunt id est", zob. Les Ampoules de Monza, DACL I 1737-1738; por. też Rerum Italicarum Scriptores, a cura di L.A. Muratori, XII, Mediolani 1728, 1071 i 1093; Jastrzębowska, Najstarsze zachowane dewocjonalia pielgrzymie z Jerozolimy, s. 60.

${ }^{12}$ Por. Nees, Early Medieval Art, s. 107, il. 64, dziś znajdują się w Museo del Duomo w Monza (12 km na północ od Mediolanu) oraz w Muzeum św. Kolumbana w Bobbio.
} 
tkaniną. Posiadają rozmiary 7,5 $\mathrm{mm}$ x $5,7 \mathrm{~mm}$. Awers ampułki zawiera pas z inskrypcją w języku greckim, który kręgiem otacza brzusiec; niektóre sceny zawierają także wewnątrz repusowane pojedyncze słowa.

1. Literatura przedmiotu. Literatura poświęcona ampułkom oraz flaszkom pielgrzymkowym, jest już dzisiaj ogromna ${ }^{13}$. Grupa flaszek z omawianego tutaj zbioru, od kilkudziesięciu lat budzi wielkie zainteresowanie. Styl repusowanych scen ampułek wywodzony jest generalnie ze sztuki syropalestyńskiej. Podstawowym opracowaniem dotyczącym ampułek z kolekcji Bobbio - Monza jest studium André Grabara ${ }^{14}$, który dokonał numeracji ampułek, stosowanej do dziś przez badaczy przedmiotu. Inną ważną pozycją bibliograficzną jest praca Kurta Weitzmanna ${ }^{15}$, który omawia wczesnobizantyńską ikonografię sztuki Palestyny i Synaju. Odnośnie inspiracji dla przedstawień na ampułkach (Monza 3, 10, 16) wskazuje na ikony z Synaju, relikwiarz z Sancta Sanctorum, dekoracje absyd kaplic klasztornych w Bawit (Egipt) oraz syryjskie iluminatorstwo (głównie Ewangeliarz Rabuli z 586 roku) ${ }^{16}$. Ikony na Synaju łączy z ikonografią ampułek; jego zdaniem - „narracyjny typ" przedstawień jest zbieżny z palestyńską sztuką VI wieku ${ }^{17}$. W innej publikacji, ikonografia ampułek ukazujących Golgotę i grób Chrystusa, została nazwana „malowaną mapą pielgrzymki” 18 i porównana do mozaiki z Madaby, ukazującej miejsca pielgrzymkowe Ziemi Świętej ${ }^{19}$. Z kolei Ernest Kitzinger pisząc na temat chrześcijańskiej ikonografii wschodniej VI-VII w., scen biblijnych obecnych na pierścieniach, bransoletach o charakterze apotropaicznym oraz na ampułkach pielgrzymich, odnośnie ikonografii biblijnej wskazuje na tworzącą się w okresie post-justyniańskim sztukę cyklów malarskich (np. opiewających życie Chrystusa) ${ }^{20}$. Natomiast Gary Vikan w swojej pracy, poświęconej sztuce pielgrzymkowej Bizancjum, omawia ampułki, flaszki,

${ }^{13} \mathrm{Na}$ temat ampułek i flaszek pielgrzymkowych produkowanych na chrześcijańskim Wschodzie, głównie w Palestynie i Syrii, w okresie wczesnobizantyńskim zob. m.in. A.M. Maeir - Y. Strauss, A Pilgrim Flask of Anatolian Origin from Late Byzantine/Early Ummayyad Jerusalem, „Anatolian Studies” 45 (1995) 237-241; W. Anderson, An Archaeology of Late Antique Pilgrim Flasks, „Anatolian Studies" 54 (2004) 79-93.

${ }^{14}$ Por. A. Grabar, Les Ampoules de Terre Sainte (Monza, Bobbio), Paris 1958.

${ }^{15}$ Por. K. Weitzmann, Loca Sancta and the Representational Arts of Palestine, DOP 28 (1974) $31-55$.

${ }^{16}$ Por. P. Szczur, Rabuli Ewangeliarz, EK XVI 1024-1025.

${ }^{17}$ Por. tamże, s. 50.

${ }^{18}$ Por. M.E. Frazer, Holy Sites representations, w: Age of Spirituality. Late Antique and Early Christian Art, Third to Seventh Century. Catalogue of the Exhibition at The Metropolitan Museum of Art, November 19, 1977, through February 12, 1978, ed. K. Weitzmann, New York 1979, 566, il. $78-79$.

${ }^{19}$ Por. tamże.

${ }^{20}$ Por. E. Kitzinger, Christian imagery: Growth and Impact, w: Age of Spirituality: A symposium, New York 1980,152-153. 
amulety; funkcję tych przedmiotów określa jako profilaktyczną i apotropaiczną, a ich ikonografię określa mianem wczesnobizantyńskiej kręgu wschodniośródziemnomorskiego ${ }^{21}$. Niemiecka badaczka Lieselotte Kötzsche porównuje omawiane ampułki do tych, które znajdują się w Muzeum w Berlinie (dziś w Frühchristlich-Byzantinische Sammlung, Skulpturengalerie, Berlin), datowanych także na VI/VII wiek, mających bardzo podobną ikonografię ${ }^{22}$. Scenę kobiety u grobu porównuje ona z bizantyńskimi psałterzami z XII wieku (tzw. Egertona 1139, fol. 9 i 10 ) i XII-wiecznymi bizantyńskimi bullami ${ }^{23}$. Wśród polskich badaczy, Elżbieta Jastrzębowska, opowiada się za tezą K. Weitzmanna, co do inspiracji ikonograficznych ${ }^{24}$. Vicky Foscalou, omawia centra pielgrzymkowe na Wschodzie, a w ich kontekście pamiątki, amulety i eulogia, publikuje VI/VII-wieczne medaliony ukazujące ikonografię zbliżoną do omawianych ampułek ${ }^{25}$. Eric Lapp omawia handel i ośrodki produkcji lampek żydowskich, pogańskich i chrześcijańskich, głównie terenu płn. Afryki, Palestyny i Syrii, klasyfikuje je ogólnie nazywając szkołą syro-palestyńską, i wskazuje na wspólne wzorce; nie zajmuje się jednak ikonografią ${ }^{26}$. Anna de Vincenz w swoim artykule o En Gedi - dużym żydowskim i chrześcijańskim mieście w okresie wczesnobizantyńskim - omawia odkryte tam lampki i naczynia $^{27}$. Datowane są one na okres od V do VII wieku i dekorowane krzyżem (crux gemmata) oraz motywem krzyża ponad edikulą - świątynią. Ikonografię ampułek porównuje ona $\mathrm{z}$ ampułkami z Bobbio - Monza, oraz dekoracją płyty marmurowej z Tabgha ${ }^{28}$. Bianca Kühnel, w jednej z ostatnich publikacji na ten temat, zajmuje się ikonografią przede wszystkim ampułek z Bobbio (według

${ }^{21}$ Por. G. Vikan, Early Bizantine Pilgrimage Art, Washington 1982, 2007², 22-24.

${ }^{22}$ Por. L. Kötzsche, Zwei Jerusalemer Pilgerampullen aus der Kreuzfahrerzeit, ,Zeitschrift für Kunstgeschichte" 51 (1988) 13-32, spec. s. 14, 15-17, il. 1-10.

${ }^{23}$ Por. tamże, il. 15-17.

${ }^{24}$ Por. Jastrzębowska, Najstarsze zachowane dewocjonalia pielgrzymie z Jerozolimy, s. 65.

${ }^{25}$ Por. V. Foskolou, A Journey to the Barrier Travel Places of the Eastern Mediterranean Area: „Souvenirs”, Customs and Mentality of the Barrier Travel Nature, „Peregrinations” 2 (2008) nr 2, http://peregrinations.kenyon.edu/vol2_2.pdf.

${ }^{26}$ Por. E.C. Lapp, Marketing Re $\bar{l}$ igious Difference in Late Antique Syria-Palestine: Clay Oil Lamps as Clientele Indicators, w: The Archaeology of Difference: Gender, Ethnicity, Class and the "other" in Antiquity: Studies in honor of Eric M. Meyers, ed. D.R. Edwards - C.T. McCollough, Boston 2007, 371-380.

${ }^{27}$ Por. A. de Vincenz, Christians Among Jews in En-Gedi, w: The Archaeology of Difference, s. 392-396; taż, Crux Gemmata Representation on a Lamp from Ein Gedi, „Bulletin of the AngloIsrael Archaeological Society” 21 (2003) 39-43; zob. też D. Barag, Glass Pilgrim Vessels from Jerusalem (part 1), „Journal of Glass Studies 12 (1970) 35-63; J. Magness, Illuminating Byzantine Jerusalem: Oil Lamps Shed Light on Early Christian Worship, „Biblical Archaeology Review” 24 (1998) nr 2, 41-47 i 70-71.

${ }^{28}$ Por. De Vincenz, Christians Among Jews in En-Gedi, s. 393-394. Na temat motywu martyrionu - edikuli, także w kontekście ampułek z Bobbio - Monza zob. R. Ousterhout, The Temple, the Sepulchre, and the Martyrion of the Savior, „Gesta” 29 (1990) nr 1, 44-53. 
chronologii A. Grabara ampułkami: Bobbio 1, 11, 20 i Monza 16) ${ }^{29}$. Poszukując pierwowzorów dla ikonografii Wniebowstąpienia i Paruzji wskazuje na syryjskie manuskrypty, absydę kościoła św. Dawida w Tesalonikach i drzwi kościoła Santa Sabina w Rzymie, a także na szerzący się w tym okresie kult krzyża i liturgię Adoracji krzyża ${ }^{30}$.

2. Program ikonograficzny. Analiza programu ikonograficznego ampułek napotyka na trudności. Rzetelna analiza wymaga bowiem precyzyjnego zestawienia przedstawień obu stron ampułek, co nie zawsze jest możliwe, nadto duża część z nich jest zniszczona, nie wszystkie są też opisane. Na podstawie zebranego materiału możemy jednak stwierdzić, ze program ikonograficzny ampułek nie był nadmiernie rozbudowany, a nadto był dość ustalony. Generalnie ma on charakter chrystologiczno-maryjny. Niemal wszyscy badacze porównują styl i kompozycję ampułek, ukazujących sceny chrystologiczne, z fragmentami ampułki przechowywanej w Dumbarton Oaks Collection w Waszyngtonie (il. 6), gdzie scenę, ukazaną na przykładach ze zbioru Bobbio - Monza na jednej stronie, podzielono na dwa i umieszczono na dwóch stronach, co pozwala nam lepiej przyjrzeć się szczegółom.

Pierwszy typ „,chrystologiczny” jest najbardziej popularny, możemy nawet powiedzieć, że zdecydowana większość ukazuje ten typ ikonograficzny. Są to następujące sceny: Śmierć i Zmartwychwstanie Chrystusa ujęte w sposób symboliczny oraz, na drugiej stronie, Wniebowstąpienie i Zesłanie Ducha Świętego.

1. (na przykładzie Monza 11), awers: u góry - pomiędzy dwoma łotrami, popiersie brodatego Chrystusa w aureoli umieszczone na wysokim krzyżu. Obok stoją Longinus i Stefaton. Na dole: grób Chrystusa, obok postać anioła i dwie kobiety (il. 1a). Rewers: Wniebowstapienie - Chrystus w mandorli niesionej przez czterech aniołów, poniżej zaś symetrycznie stoi Madonna z Apostołami (il. 1b) ${ }^{31}$.

2. (na przykładzie Monza 9), awers: popiersie brodatego Chrystusa w aureoli umieszczone na wysokim krzyżu, pomiędzy dwoma łotrami. Obok stoją Longinus i Stefaton, dalej Madonna ze św. Janem, poniżej grób Chrystusa z aniołami; rewers: całą scenę zajmuje Chrystus z Apostołami i niewiernym Tomaszem (il. 2) ${ }^{32}$. Podobny symbolicznie układ: Śmierć i Zmartwychwstanie, z drugiej - krzyż w arkadzie

${ }^{29}$ Por. B. Kühnel, The Holy Land as a Factor in Christian Art, w: Christians and Christianity in the Holy Land. From the Origins to the Latin Kingdoms, ed. O. Limor - G.G. Stroumsa, Tournhout 2006, 463-504, spec. 473-484.

${ }^{30}$ Por. Kühnel, The Holy Land as a Factor in Christian Art, s. 475 i 478-479.

${ }^{31}$ Identyczny układ ikonograficzny widzimy na innej ampułce z Monza, zob. Ampoules (A Eulogies), DACL I 1738-1740, il. 458.

${ }^{32}$ Por. tamże, DACL I 1737-1738, il. 457. 
z popiersiami 12 Apostołów w tondzie, i dalej 29 gwiazd publikują F. Cabrol i H. Leclercq ${ }^{33}$.

Typ „maryjny” zaś to sceny z życia Chrystusa i Maryi, ale z akcentem położonym na Madonnę. Głównym przedstawieniem jest tu Madonna tronująca w scenie Zwiastowania, Adoracja Pasterzy i Pokłon Magów, na rewersie zaś, bądź Madonna i Apostołowie w scenie Wniebowstąpienia, bądź sceny z życia Chrystusa z centralną sceną Narodzin.

1. (przykład Monza 1), awers: jedna strona ukazuje Madonnę z Dzieciątkiem, Adorację Magów i Zwiastowanie Pasterzom, poniżej ozdobnej belki - grupe jeźdźców (il. 3a, 4a) ${ }^{34}$; rewers: Wniebowstąpienie, czyli Chrystus w mandorli niesionej przez czterech aniołów, poniżej symetrycznie - Madonna z Apostołami stojąca na wyraźnie zaznaczonej ziemi, pod nią zaś motyw roślinny.

2. przykład podobny: awers: Madonna i Adoracja Magów; rewers: Grób Chrystusa, aniołowie i dwie Marie oraz 12 Apostołów w formie popiersi (il. 4a i b).

3. (przykład Monza 2), awers: jak wyżej Adoracja Magów i Zwiastowanie Pasterzom; rewers: kompozycja złożona z siedmiu scen chrystologiczno-maryjnych, zamkniętych w koła (il. 5). W centrum znajduje się scena Narodzin, a wokół niej siedem tond ze scenami z życia Chrystusa: Zwiastowanie Maryi ${ }^{35}$, Chrzest, Wniebowstąpienie, Grób Chrystusa $\mathrm{z}$ aniołem i 2 kobietami oraz 3 sceny niezidentyfikowane.

G. Vikan, L. Nees i B. Kühnel ${ }^{36}$ przedstawiają także fragmenty ampułek (bardzo zniszczone) z Bobbio (Bobbio 1, 11 i 20), w których pojawiają się nowe elementy ikonograficzne, m.in. scena ukazująca Chrystusa idącego po wodzie oraz motyw crux gemmata na pagórku (Paruzja). Stan zachowania ampułek nie pozwala jednak na dokładną rekonstrukcję ich ikonografii.

Warto zwrócić uwagę, że chociaż ikonografia ampułek jest dość ustalona, to architektura Grobu Pańskiego jest zróżnicowana (il. 7). Jest to budowla na planie czworoboku lub wieloboku przekryta prawdopodobnie schowana kopuła, w innym wypadku jest to budowla pod baldachimem, rodzaj cyborium. Odnośnie prowadzonych studiów nad architekturą Armenii, ten typ architektury A. Khatchatrian porównuje do formuły architektonicznej grobowej

${ }^{33}$ Por. Astres, DACL I 3023, il 1056.

${ }^{34}$ Por. Vikan, Early Bizantine Pilgrimage Art, s. 23, il. 16; Jastrzębowska, Najstarsze zachowane dewocjonalia pielgrzymie z Jerozolimy, s. 61.

${ }^{35}$ Odnośnie tej sceny na ampułce, w której A. van Dijk widzi scenę zwiastowania por. A. van Dijk, The Angelic Salutation in Early Byzantine and Medieval Annunciation Imagery, „, The Art Bulletin" 81 (1999) nr 3 430-432, il. 13.

${ }^{36}$ Dziś w Museo di S. Colombano w Bobbio, zob. Nees, Early Medieval Art, s. 119, il. 70; Kühnel, The Holy Land as a Factor in Christian Art, s. 475, fig. 5; s. 477, fig. 7; Vikan, Early Bizantine Pilgrimage Art, s. 24, fig. 18. 
późnorzymskiej, szczególnie syryjskiej - cyborium z kopułą - te zaś wywodzi z Persji ${ }^{37}$. P. Donabédian, powołując się na teorię Khatchatriana, najlepszą realizację artystyczną tej formy architektonicznej widzi właśnie w przedstawieniach na ampułkach palestyńskich z Monza ${ }^{38}$.

\section{PALESTINIAN AMPOULES FROM THE COLLECTION OF MONZA - BOBBIO. ICONOGRAPHIC PROGRAM}

\section{(Summary)}

The article presents iconographic types of Palestinian ampoules from the collection Monza - Bobbio. The author propos two types of iconography and compositions of ampoules, Christological (Monza 11, 9) and Mariological (Monza 1,2). The style carved scenes presents eastern style and iconography VI-VII century, especially Syrian and Palestinian.

Key words: Ampules of Monza - Bobbio, pilgrimage art, pilgrim flask.

Slowa kluczowe: ampułki z Monza - Bobbio, sztuka pielgrzymkowa, pielgrzymie buteleczki.

\section{BIBLIOGRAFIA}

Anderson W., An Archaeology of Late Antique Pilgrim Flasks, „Anatolian Studies” 54 (2004) 79-93.

Grabar A., Les Ampoules de Terre Sainte (Monza, Bobbio), Paris 1958.

JASTRZĘBOwska E., Najstarsze zachowane dewocjonalia pielgrzymie z Jerozolimy, w: Jerozolima w kulturze europejskiej, red. P. Paszkiewicz - T. Zadrożny, Warszawa 1997, 59-69.

Kötzsche L., Zwei Jerusalemer Pilgerampullen aus der Kreuzfahrerzeit, „Zeitschrift für Kunstgeschichte" 51 (1988) 13-32.

${ }^{37}$ Podaję za: P. Donabédian, Les débuts de l'architecture chrétienne en Orient: Les premières églises à coupole d'Arménie, w: L'archéologie du bâti en Europe. Archeologia domobudiwnictwa Evropi, Kiev 2013, 347: „Par ailleurs, on sait que des sanctuaires du feu (autels dits «ateshgah» ou «tchahartak» en perse, « atroushan » en arménien) ont été érigés en Arménie par les Perses : les sources confirment qu'il a existé en Arménie, avant et après la christianisation, de tells pyrées mazdéens, constructions tétrapodes à coupole. Il s'agit du même principe que celui du baldaquin ou ciborium, présent dans l'architecture funéraire romaine tardive, notamment de Syrie"; zob. też A. Grabar, Martyrium. Recherché sur les culte des reliques et l'art chrétien antique, London 1972; B. Filarska, Poczqtki architektury chrześcijańskiej, Lublin 1983, 162-164 (budowla na Golgocie), 201-203 (Martyrion), 187 (budowle centralne).

${ }^{38}$ Por. Donabédian, Les débuts de l'architecture chrétienne en Orient, s. 347: „La manifestation la plus éminente de cette forme se trouvait sur le tombeau du Christ, sous la rotonde de l'Anastasis (Saint-Sépulcre) de Jérusalem, comme le montrent notamment les ampoules paléochrétiennes de Terre Sainte". Powołuje się na następujące przykłady z opracowania A. Grabara, Ampoules de Terre Sainte (Monza - Bobbio), Paris 1958, s. 20, 22, 25, 28, 58, pl. IX, XI, XIV. 
Maeir A.M.- Strauss Y., A Pilgrim Flask of Anatolian Origin from Late Byzantine/Early

Ummayyad Jerusalem, „Anatolian Studies” 45 (1995) 237-241.

VIKan G., Early Bizantine Pilgrimage Art, Washington 1982, $2007^{2}$.

Weitzmann K., Loca Sancta and the Representational Arts of Palestine, DOP 28 (1974) $31-55$.

\section{ANEKS}
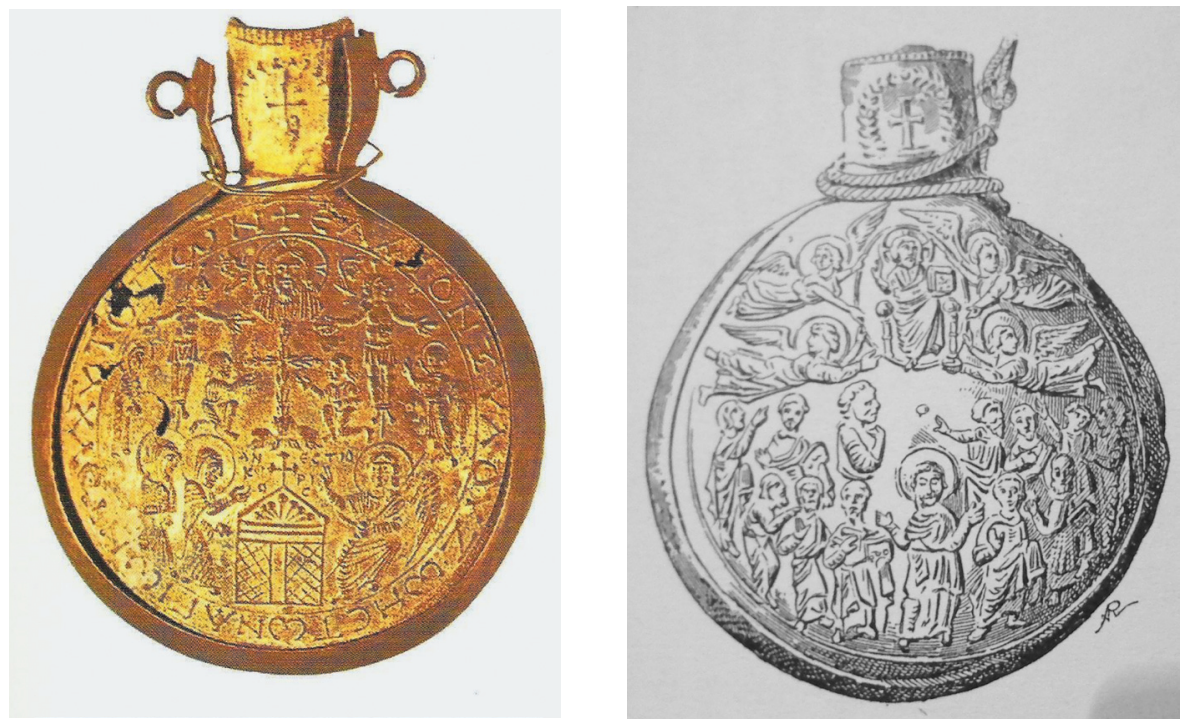

Il. 1a i b. Monza 11: Ukrzyżowanie (głowa Chrystusa w tondzie) i kobiety u grobu, Wniebowstapienie i Madonna z Apostołami, Jerozolima, ok. 600, Monza, skarbiec Katedry św. Jana Chrzciciela, według: J. Lassus, Frühchristliche und byzantinische Welt. Architektur, Plastik, Mosaiken, Fresken, Elfenbeinkunst, Mettallarbeiten, Paris 1969, s. 38, il. 49; DACL I 1739-1740, il. 458. 

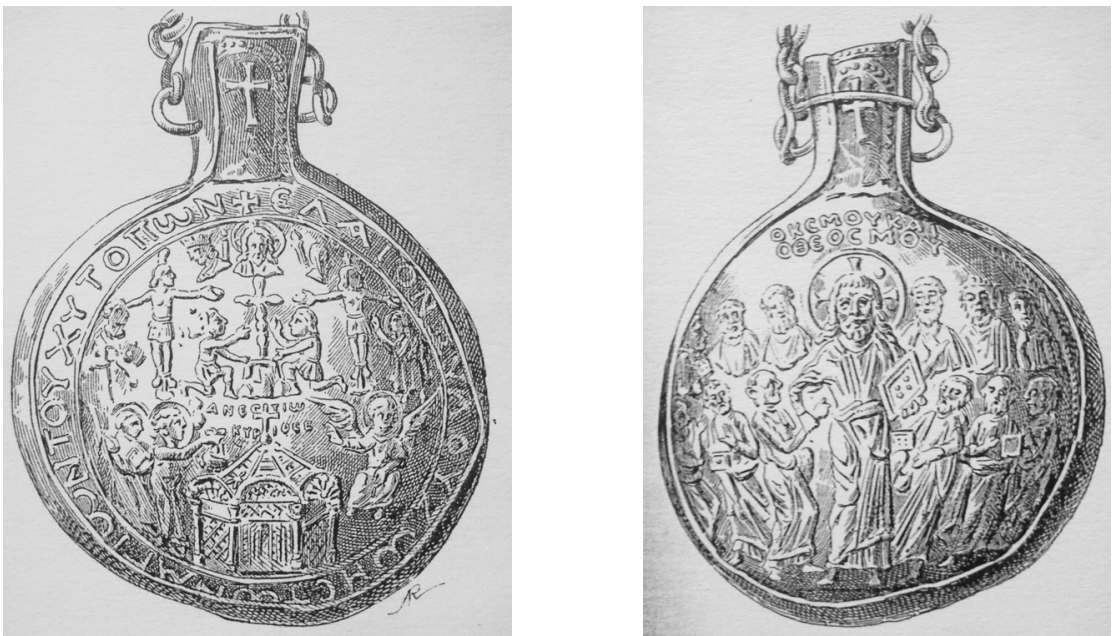

Il. 2a i b. Monza 9: Ukrzyżowanie i kobiety u grobu, epizod z niewiernym Tomaszem, Jerozolima, ok. 600, Monza, skarbiec Katedry św. Jana Chrzciciela, według: DACL I 1737-1738, il. 457; zob. też: Vikan, Early Bizantine Pilgrimage Art, s. 25, il. 19.
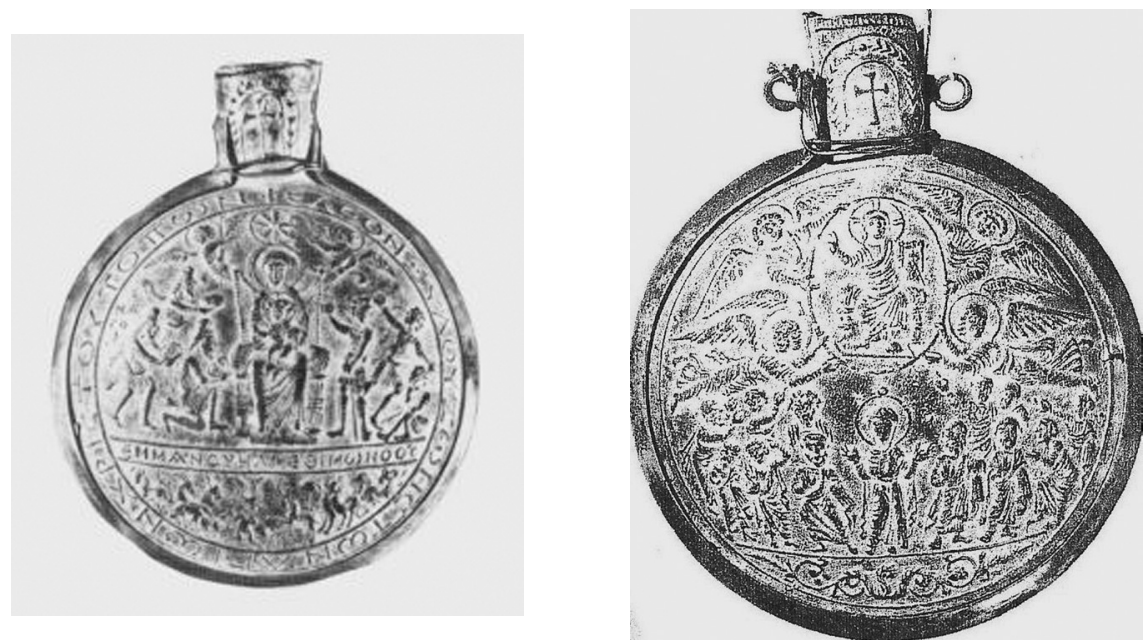

Il. 3a i b. Monza 1: Adoracja Magów i Pokłon Pasterzy, Jerozolima ok. 600, Monza, skarbiec Katedry św. Jana Chrzciciela, według: Vican, Early Bizantine Pilgrimage Art, s. 23, il. 16; zob. też DACL I 1741-42, il. 460. 

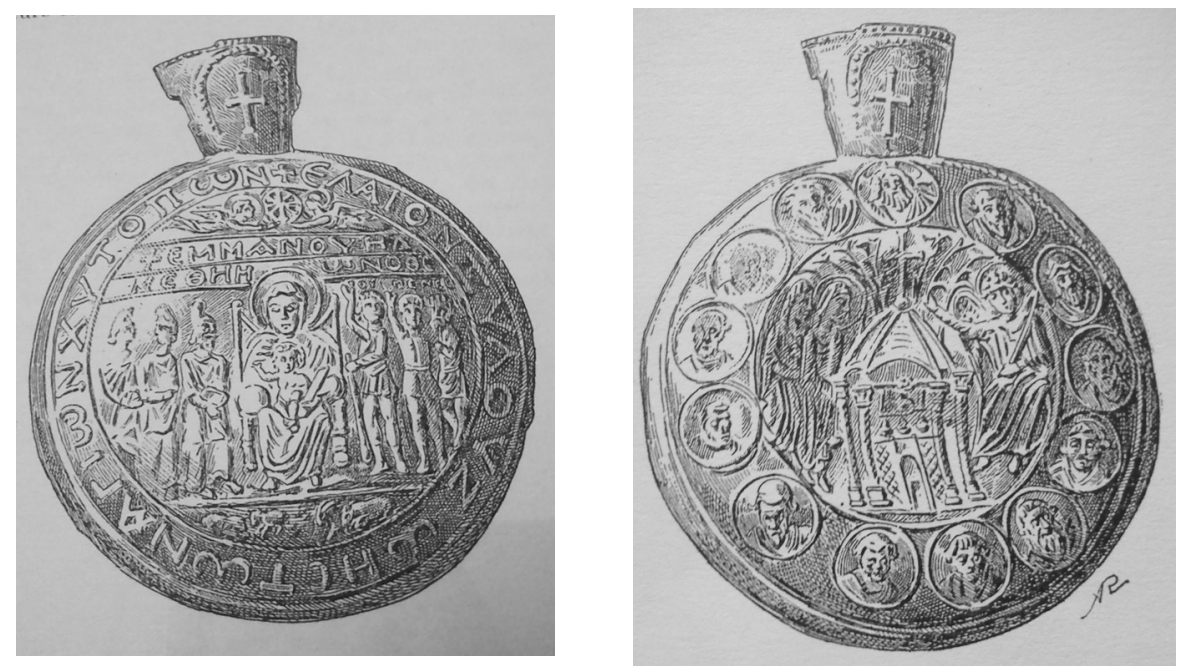

Il. 4a i b. Madonna z Dzieciątkiem, Adoracja Magów. Grób Chrystusa, anioł i dwie Marie oraz 12 popiersi apostołów, według: DACL I 1743-1744, il. 461.

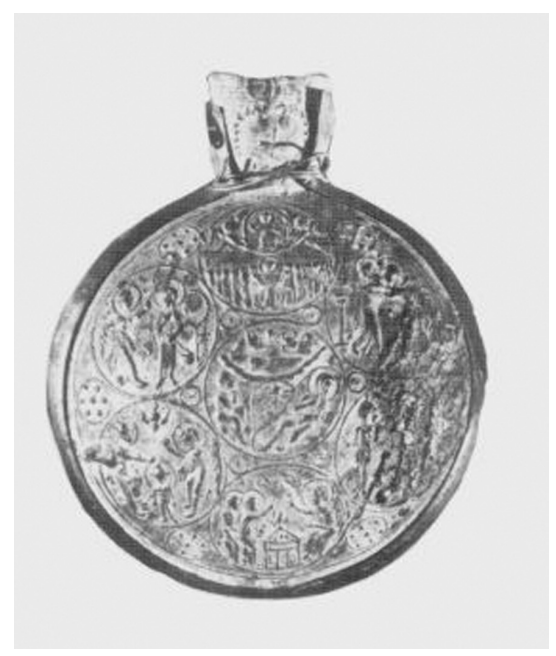

Il. 5. Monza 2: sceny z życia Chrystusa i Maryi, Jerozolima, ok. 600, Monza, skarbiec Katedry św. Jana Chrzciciela, według: Vican, Early Bizantine Pilgrimage Art, s. 42, il. 34; F. Winkelman - G. Gomolka Fuchs, Frühbzyantinische Kultur, Leipzig 1987, s. 64, il. 35. 

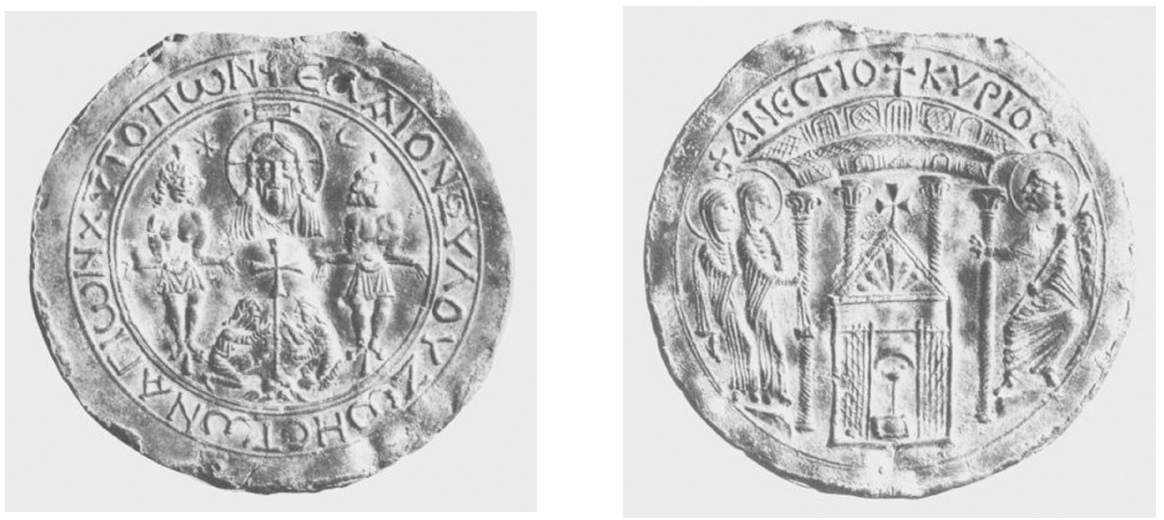

Il. 6. Fragmenty ampułki z Dumbarton Oaks Collection w Waszyngtonie, według: Vikan, Early Bizantine Pilgrimage Art, obwoluta.
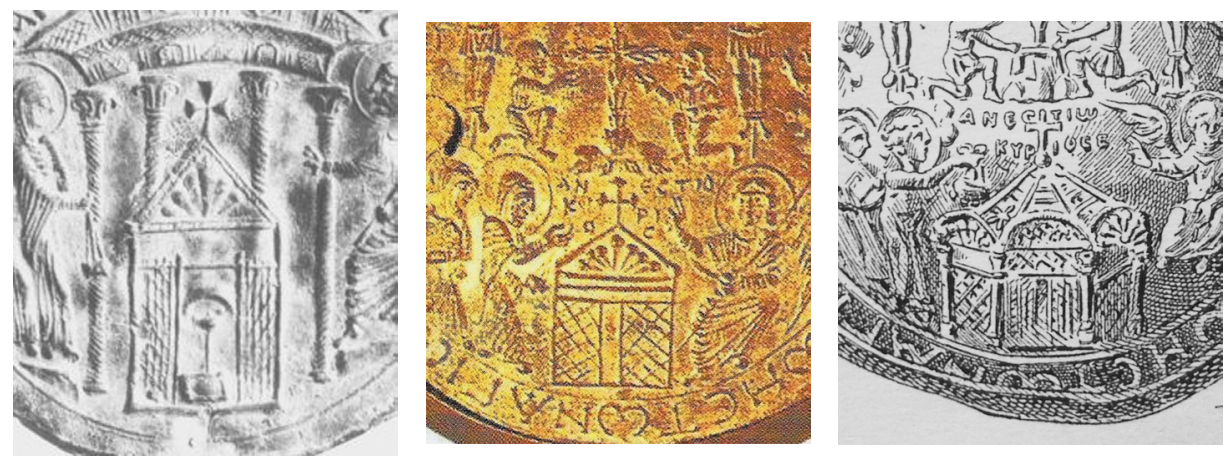

Il. 7. Fragmenty ampułek z Dumbarton Oaks Collection, ampułki 11 i 9 z Monza. 
